\title{
Trzy argumenty przeciwko kontekstualizmowi epistemicznemu
}

\author{
Maria Ebner \\ (Uniwersytet Warszawski, Wydział Filozofii)
}

\section{Wprowadzenie}

Kontekstualizm epistemiczny spotyka się z różnego rodzaju krytyką. Część zarzutów dotyczy kontekstualistycznego ujęcia zdań przypisujących wiedzę i znajdują one zastosowanie także w odniesieniu do innych wyrażeń uznawanych za zależne od kontekstu. Inny rodzaj zarzutów jest ściśle związany z przyjmowaniem kontekstowej zależności słowa „wiedzieć” i na ogół zarzuty z tej grupy nie są odnoszone do innych wyrażeń zaliczanych do wrażliwych na zmianę kontekstu - co nie znaczy, że przy odrobinie pomysłowości i wprowadzeniu pewnych modyfikacji nie byłoby to możliwe. Trzy argumenty wymierzone przeciw kontekstualizmowi epistemicznemu stanowiące przedmiot niniejszego artykułu należą do obu $\mathrm{z}$ wymienionych grup. Pierwsze dwa nie są ściśle związane z kontekstualistycznym opisem słowa „wiedzieć” czy zdań przypisujących wiedzę, natomiast trzeci - już tak.

Owe trzy argumenty są następujące (w kolejności, w jakiej zostaną omówione):

1. Argument odwołujący się do sytuacji sporu pomiędzy rozmówcami $\mathrm{w}$ kwestii przypisania pewnemu podmiotowi (lub pewnym podmiotom) wiedzy.

2. Argument polegający na przedstawieniu dialogu, w którym jeden z rozmówców zmienia zdanie. Chociaż wypowiadane kwestie są zgodne z wy- 
tycznymi kontekstualizmu, pojawiają się poważne wątpliwości co do właściwości (czy też, przy innej interpretacji: prawdziwości) niektórych wypowiedzeń.

3. Argument, który - wychodząc od analogii pomiędzy funkcjonowaniem słowa „wiedzieć" a funkcjonowaniem wyrażeń zaliczanych do podstawowego zestawu wyrażeń okazjonalnych oraz wyrażeń wieloznacznych - ma na celu wykazanie, że kontekstualizm nie jest interesującym stanowiskiem teoretycznym z punktu widzenia podstawowych pytań epistemologicznych.

Jakie racje można wymienić dla wyboru tych właśnie zarzutów pod adresem kontekstualizmu spośród wielu innych? Dwa z zaprezentowanych argumentów wskazują na trudności, przed którymi staje kontekstualizm ze względu na niezgodności z praktyką językową. Rozważając kontekst sporu, stajemy przed pytaniem, czy taki spór ma prawo mieć miejsce na gruncie przyjętych założeń teoretycznych. Przewidywania kontekstualizmu wydają się niesłuszne także w wypadku kontekstu zmiany zdania (czy nie dysponujemy prawem oceny naszych poglądów jako błędnych, także kiedy związane są z dokonywanymi askrypcjami wiedzy?).

Wybór trzeciego argumentu został podyktowany odmiennego rodzaju racją. Ponieważ kontekstualizm epistemiczny jest traktowany z reguły zarówno przez swoich zwolenników, jak i oponentów nie jako l’art pour l’art, ale ważny głos $\mathrm{w}$ sprawie istotnych zagadnień epistemologicznych, trzeba sobie postawić pytanie, czy ten głos jest w ogóle relewantny w dyskusji nad naturą i warunkami wiedzy, czy też nie ma w tej debacie żadnego znaczenia. Jest to pytanie, które podejmuje Ernest Sosa w tekście Skepticism and Contextualism.

\section{Zdania przypisujące wiedzę w ujęciu kontekstualizmu}

Podstawową kwestią, która wymaga poruszenia, jest dokonanie zwięzłej charakterystyki kontekstualistycznego ujęcia zdań przypisujących wiedzę. Na gruncie tego stanowiska sąd wyrażany przez zdanie o postaci „S wie, że $p$ ” zależy od okoliczności wypowiedzenia tego zdania. O ile pewne parametry kontekstu podlegają określonego rodzaju zmianom, o tyle odpowiednio zmienia się także treść zdania. Innymi słowy: kontekstualiści twierdzą, że różni rozmówcy posługują 
się różnymi pojęciami wiedzy w różnych sytuacjach (bądź też jeden rozmówca posługuje się różnymi pojęciami wiedzy w zależności od okoliczności rozmowy).

Kontekstualiści starają się uzasadnić taką koncepcję mechanizmów semantycznych związanych z funkcjonowaniem słowa „wiedzieć” poprzez przedstawienie przekonujących przykładów, skłaniających do przyznania różnej wartości logicznej zdaniu przypisującemu wiedzę danemu podmiotowi w danej sprawie w zależności od okoliczności wypowiedzenia. Przyjrzyjmy się jednemu takiemu przykładowi w celu zilustrowania strategii, którą posługują się kontekstualiści (przykład ten zaczerpnęłam od Cohena i przedstawiam w zmodyfikowanej postaci) ${ }^{1}$ :

\section{Sytuacja A:}

Maria i Jan znajdują się na lotnisku i mają zamiar polecieć do Nowego Jorku. Chcą się dowiedzieć, czy ich samolot będzie miał międzylądowanie w Chicago. Słyszą, jak ktoś pyta oczekującego na ten sam lot Smitha, czy samolot będzie miał międzylądowanie w Chicago. Smith spogląda na rozkład lotów i odpowiada: „Tak, samolot będzie miał międzylądowanie w Chicago”. Ponieważ kwestia międzylądowania nie ma tak wielkiego znaczenia (chodzi tylko o kupienie perfum dla krewnej, co można zrobić także w innym miejscu), Maria stwierdza: „Smith wie, że samolot będzie miał międzylądowanie w Chicago. Będziemy mogli kupić tam perfumy".

\section{Sytuacja B:}

Małgorzata i Piotr znajdują się wraz z Marią i Janem na lotnisku. Zamierzają udać się do Nowego Jorku. Chcą się dowiedzieć, czy samolot będzie miał międzylądowanie w Chicago. Słyszą, jak ktoś pyta oczekującego na ten sam lot Smitha, czy samolot będzie miał międzylądowanie w Chicago. Smith spogląda na rozkład lotów i odpowiada: „Tak, samolot będzie miał międzylądowanie w Chicago”. Okazuje się, że Małgorzata i Piotr mają bardzo ważne spotkanie biznesowe na lotnisku w Chicago. Małgorzata stwierdza: „Rozkład lotów może zawierać błąd. Smith nie wie, że samolot będzie miał międzylądowanie w Chicago. Lepiej zasięgnijmy informacji z bardziej wiarygodnego źródła, na przykład od kontrolera lotów”.

S. Cohen, Contextualism, Skepticism, and the Structure of Reasons, „Philosophical Perspectives” 1999, Vol. 13, s. 58. 
Rozważmy obie przedstawione sytuacje w duchu kontekstualizmu. W sytuacji A Maria przypisuje Smithowi wiedzę w kwestii międzylądowania ze względu na obowiązywanie niższych standardów epistemicznych niż w sytuacji B - natomiast pozycja epistemiczna Smitha względem sądu, że samolot będzie miał międzylądowanie w Chicago nie ulega zmianie, ponieważ uzasadnieniem dla przekonania Smitha jest i w jednym, i w drugim wypadku informacja zawarta w rozkładzie lotów. Sytuacja B charakteryzuje się o wiele wyższymi standardami epistemicznymi, którym Smith nie jest w stanie sprostać, co sprawia, że Małgorzata jest skłonna zaprzeczyć prawdziwości zdania „Smith wie, że samolot będzie miał międzylądowanie w Chicago".

\section{Pierwszy zarzut przeciw kontekstualizmowi}

Zastanówmy się jednak, czy gdyby Maria i Małgorzata spotkały się i zaczęły dyskutować na temat dysponowania przez Smitha wiedzą w kwestii międzylądowania, kontekstualizm potrafiłby wyjaśnić istotę sporu pomiędzy rozmówczyniami? Skoro sądy wyrażane przez zdanie „Smith wie, że samolot będzie miał międzylądowanie w Chicago" są różne w sytuacji A i sytuacji B, to wydaje się, że spór jest de facto sporem pozornym.

Przedstawmy zarzut związany z sytuacją sporu pomiędzy rozmówcami, posługując się odmiennym przykładem:

Maria i Jan interesują się historią sztuki i prowadzą ze sobą dyskusję dotyczącą atrybucji Koncertu wiejskiego. Maria stwierdza: „Nareszcie wiemy, kto namalował Koncert wiejski. Historycy sztuki ustalili, że autorem tego arcydzieła jest Tycjan”. Jan replikuje: „Jednak nie wszyscy zgadzają się z takim wnioskiem. Wielu historyków wciąż przypisuje ten obraz pędzlowi Giorgionego, za czym przemawiają charakterystyczne elementy stylistyczne. Ciągle nie mamy pewności w tej sprawie".

Czy mamy w przedstawionym powyżej wypadku do czynienia $\mathrm{z}$ autentycznym sporem? O ile jesteśmy skłonni odpowiedzieć na to pytanie twierdząco, kontekstualizm musi wyjaśnić taką sytuację, co prima facie stanowi istotną trudność dla tego stanowiska teoretycznego². Skoro Maria i Jan operują różnymi

Kontekstualizm określony mianem „relatywizmu okazjonalnego” został zaliczony przez Maxa

Kölbela do zbioru stanowisk, które nie dopuszczają istnienia pozbawionych błędów sporów 
pojęciami wiedzy (przypisanie wiedzy przez Jana wymaga spełnienia wyższych standardów epistemicznych niż przypisanie wiedzy przez Marię), spór jawi się jako pozorny, ponieważ argumentowanie na rzecz własnego stanowiska wydaje się pozbawione jakiegokolwiek przekonującego uzasadnienia z punktu widzenia adwersarza. Jeśli rzeczywiście brak jakiegokolwiek kryterium pozwalającego rozstrzygnąć, które standardy są obowiązujące w sytuacji rozważanej rozmowy, każdy z rozmówców pozostaje przy swoim zdaniu (Maria twierdzi „Wiemy, kto jest autorem Koncertu wiejskiego”, Jan obstaje przy zdaniu „Nie wiemy, kto jest autorem Koncertu wiejskiego") i nie zostaje wypracowany żaden konsensus ${ }^{3}$.

Jednak kontekstualista może zarówno zdecydować, że w ramach danej rozmowy obowiązują, jak określa to DeRose, „osobiste tablice wyników” (personal scoreboards), jak i utrzymywać, że uczestnicy rozmowy posiadają „wspólną tablicę wyników" (single scoreboard) ${ }^{4}$.

W pierwszym wypadku warunkowoprawdziwościowa treść słowa „wiedzieć” zostaje wyznaczona odrębnie dla obu osób zaangażowanych w spór, co może prowadzić do konkluzji - o ile nie uznamy jednego z używanych pojęć wiedzy za uprzywilejowane w danej sytuacji - że nie istnieje żadne racjonalne rozstrzygnięcie sporu.

(„faultless disagreements”). W sytuacji takiego rodzaju sporu rozmówcy wygłaszają sprzeczne ze sobą twierdzenia (jedna ze stron konfliktu twierdzi, że $p$, a druga twierdzi, że nie- $p$ ), a mimo to żadna z zaangażowanych osób nie popełnia błędu (M. Kölbel, Faultless Disagreement, „Proceedings of the Aristotelian Society" 2004, Vol. 104, s. 53-54). Ponieważ na gruncie relatywizmu okazjonalnego treść zdania $p$ jest zmienna w zależności od modyfikacji określonych parametrów kontekstu, wygłoszenie zdania nie- $p$ niekoniecznie prowadzi do zanegowania sądu wyrażonego przez zdanie $p$. Stanowiskiem przeciwstawnym (i konkurencyjnym) wobec relatywizmu okazjonalnego jest relatywizm. Dopuszcza on, że zdarzają się sytuacje sporu, w których żadna strona nie popełnia błędu. Mimo że treść sprzecznych ze sobą zdań nie jest zależna od zmian kontekstu, zdanie $p$ wyrażające określony sąd może być prawdziwe ze względu na perspektywę danego rozmówcy, a fałszywe z punktu widzenia innego rozmówcy. Operowanie zrelatywizowanym pojęciem prawdy oznacza, że wygłoszenie przez jedną stronę sporu zdania $p$, a przez drugą zdania nie- $p$ niekoniecznie prowadzi do uznania, że ktokolwiek powinien zrewidować swoje poglądy.

3 Pomijam trudności wiążące się z brakiem dokładnego określenia, kogo dokładnie oznacza podmiot domyślny w analizowanych zdaniach. $\mathrm{W}$ razie pojawienia się wątpliwości zawsze możemy rozważać rozmowę dotyczącą przypisania wiedzy w sprawie autorstwa Koncertu wiejskiego konkretnej osobie.

4 K. DeRose, The Case for Contextualism: Knowledge, Skepicism and Context, Vol.1, Oxford University Press, Oxford 2009, s. 134-135, por. też R. Palczewski, Wiedza w kontekstach. W obronie kontesktualizmu epistemicznego, t. II, Wydawnictwo Naukowe UMK, Toruń 2014, s. 222-223. 
W drugim wypadku wartość logiczna wypowiadanych zdań przypisujących wiedzę jest rejestrowana wspólnie dla obu rozmówców, co sprawia, że treść tych zdań (a co za tym idzie znaczenie słowa „wiedzieć”) jest jednakowa (mimo że początkowo wydaje się różna) dla obu rozmówców. Ustalenie tej wspólnej treści jest właśnie zadaniem dla stron sporu, które wypracowują konsensus dotyczący przyjęcia określonego zestawu standardów epistemicznych. Sytuacja sporu prezentuje się nam teraz $\mathrm{w}$ nowym - zgodnym z założeniami kontekstualizmu - świetle, prowadzącym do uznania, że - o ile spór dotyczy explicite kwestii ustalenia standardów epistemicznych, ze względu na to, że wiedza dotycząca faktów (w tym wypadku argumentów wysuwanych przez historyków sztuki na poparcie przyjmowanej tezy dotyczącej atrybucji Koncertu wiejskiego) jest podzielana przez obie strony sporu - o tyle rozstrzygnięcie sporu wymaga wypracowania wspólnego stanowiska dotyczącego siły pozycji epistemicznej domniemanego podmiotu wiedzy wymaganej w danej sytuacji. Zarzut skierowany przeciwko kontekstualizmowi chybia zatem celu, ponieważ spór może mieć źródło w odmiennych zapatrywaniach różnych osób na kryteria, których spełnienia wymaga posiadanie wiedzy (nawet kiedy te zapatrywania nie zostają wyrażone wprost, a jedynie ujawniają się w skłonnościach sceptyckich jednej osoby i braku takich skłonności drugiej osoby) $)^{5}$.

\section{Drugi zarzut przeciw kontekstualizmowi}

Przejdźmy do kolejnego argumentu wysuwanego przeciwko kontekstualizmowi. Ma on inny charakter, ponieważ w przedstawionej sytuacji rozmówcy zachowują się tak, jak gdyby kontekstualizm był trafną teorią odnośnie do semantyki słowa

\footnotetext{
Mark Richard przeprowadza analogię pomiędzy sporem dotyczącym prawdziwości zdania, w którym występują przymiotniki wrażliwe kontekstowo, takie jak „bogaty”, a sporem dotyczącym kwestii przypisania komuś wiedzy. W odniesieniu do przykładu niezgody pomiędzy rozmówcami dotyczącym wartości logicznej zdania „Maria jest bogata” Richard stwierdza: „Wyłącznie werbalne nieporozumienie nie jest nieporozumieniem. Przynajmniej nie jest tak naprawdę nieporozumieniem. Twierdzę, że w wypadkachtakich jak spór nieporozumienie nie jest czysto werbalne. Jest istotne, ponieważ istnieje pojęcie, które obaj [rozmówcy] podzielają - bycia bogatym - co do którego kryteriów się nie zgadzają" (M. Richard, Contextualism and Relativism, „Philosophical Studies: An International Journal for Philosophy in the Analytic Tradition" 2004, Vol. 119, No. 1/2, s. 238).
} 
„wiedzieć", a mimo to kwestie wypowiadane przez osoby biorące udział w rozmowie brzmią niewłaściwie. Przyjrzyjmy się następującemu dialogowi:

A: Czy to jest zebra?

B: Tak, to jest zebra.

A: Ale czy potrafisz wykluczyć, że to jest po prostu sprytnie pomalowany muł?

B: Nie, nie potrafię.

A: Czy zatem przyznajesz, że nie wiedziałeś, że to jest zebra?

B: Nie, wiedziałem wówczas, że to jest zebra. Ale po twoim pytaniu już tego nie wiem 6 .

Postępowanie rozmówców przedstawionego powyżej dialogu wydaje się zgodne z wytycznymi kontekstualizmu, ponieważ w momencie, gdy rozmówca A poprzez zadane pytanie podwyższa standardy epistemiczne („Ale czy potrafisz wykluczyć, że to jest po prostu sprytnie pomalowany muł?"), osoba B odmawia sobie wiedzy w kwestii, w której przypisywała sobie wiedzę przed podwyższeniem standardów.

Kontekstualista zasadniczo może obrać dwie różne strategie odpowiedzi na zaprezentowany argument ${ }^{7}$. Zgodnie z pierwszą strategią zostaje zakwestionowane pierwsze zdanie ostatniej wypowiedzi osoby B („Nie, wiedziałem wówczas, że to jest zebra"), zgodnie $\mathrm{z}$ drugą strategią zostaje podane w wątpliwość drugie zdanie tej wypowiedzi („Ale po twoim pytaniu już tego nie wiem”). Rozważmy najpierw drugą z wymienionych strategii, która pod pewnymi względami wydaje się niesatysfakcjonująca. Kontekstualista, obierając tę strategię, przyjmuje, że samo wspomnienie alternatywnej hipotezy (czyli w tym wypadku hipotezy, że obserwowane zwierzęta to nie zebry, lecz pomalowane w paski muły) nie wystarcza do podwyższenia standardów epistemicznych. Za jeden $\mathrm{z}$ warunków uwieńczonego powodzeniem podwyższenia standardów epistemicznych może zostać uznanie takiej hipotezy za rozsądną hipotezę w danej sytuacji przez wszystkie osoby biorące udział w rozmowie ( $\mathrm{w}$ naszym przykładzie osoba $\mathrm{B}$ musi zaakceptować przedstawioną przez A hipotezę jako rozsądną w kontekście prowadzonej rozmowy).

$6 \quad$ P. Yourgrau, Knowledge and Relevant Alternatives, „Synthese” 1983, Vol. 55, No. 2, s. 183. Przykład z zebrą został przez Yourgrau zaczerpnięty z tekstu Freda Dretskego (F. Dretske, Epistemic Operators, w: Skepticism. A Contemporary Reader, eds. K. DeRose, T.A. Warfield, Oxford University Press, Oxford 1999, s. 138).

7 Por. R. Palczewski, Wiedza w kontekstach. W obronie kontesktualizmu epistemicznego, t. I, Wydawnictwo Naukowe UMK, Toruń 2014, s. 358-362. 
Problem $\mathrm{z}$ taką odpowiedzią polega, $\mathrm{w}$ odniesieniu do analizowanego przykładu, na udzielonej przez osobę B zgodzie na podwyższenie standardów epistemicznych; osoba B na końcu rozmowy zaprzecza, że wie, że zaobserwowane zwierzęta to zebry, mimo przypisywania sobie wiedzy w tej kwestii na początku dialogu. O ile wspomnienie przez rozmówcę A hipotezy o charakterze sceptyckim wydaje się nieuzasadnione bez uzupełnienia dialogu przez dodatkowe okoliczności, które czyniłyby tę hipotezę rozsądną i przekonującą, o tyle zawsze istnieje możliwość uzupełniania w taki sposób przykładu, co czyni kwestię podwyższenia standardów w toku rozmowy, jeśli nie bezdyskusyjną, to przynajmniej niepodatną na poważne wątpliwości.

Przejdźmy zatem do pierwszej z wymienionych strategii, czyli strategii podważającej zasadność przypisania sobie przez osobę B na początku rozmowy wiedzy, że zaobserwowane zwierzę to zebra (po czym natychmiast następuje stwierdzenie, że nastawienie sądzeniowe z początku dialogu mimo wszystko nie powinno zostać zakwalifikowane jako wiedza). Na gruncie kontekstualizmu przypisującego (attributor contextualism) standardy epistemiczne decydujące o tym, czy dane wypowiedzenie przypisujące wiedzę uznamy za prawdziwe to standardy obowiązujące w aktualnym kontekście osoby przypisującej wiedzę w odróżnieniu od standardów epistemicznych rządzących w kontekście, w którym znajduje się domniemany podmiot wiedzy. Może się oczywiście zdarzyć (tak jak to jest w obecnym wypadku), że podmiot przypisujący wiedzę i podmiot, któremu wiedza jest przypisywana, są jednym i tym samym podmiotem, a standardy epistemiczne obowiązujące ze względu na ten podmiot nie ulegają zmianie, niezależnie od roli, ze względu na którą jest rozpatrywany. $Z$ taką sytuacją mamy do czynienia wówczas, gdy wypowiedzenie, w którym ktoś przypisuje sobie wiedzę, zostaje dokonane w kontekście o takich samych istotnych parametrach (zwłaszcza związanych z przyjmowanymi kryteriami decydującymi o tym, czy dane przekonanie zostaje zaklasyfikowane jako wiedza) jak parametry obowiązujące w odniesieniu do kontekstu tej osoby jako domniemanego podmiotu wiedzy. Zmiana poglądów danej osoby w kwestii tego, jak dobrze powinno zostać uzasadnione przekonanie, które słusznie może pretendować do miana wiedzy (w jak silnej pozycji epistemicznej powinien znajdować się podmiot względem danego sądu) może ulec zmianie $\mathrm{w}$ czasie, co wiąże się z pojawieniem istotnych różnic w kontekście podmiotu przypisującego dokonującego wypowiedzenia w momencie $t_{2}$ (po dokonanej rewizji poglądów na kwestię uzasadniania przekonań) o postaci „S wie (w momencie $t_{1}$, czyli przed zmianą poglądów na kwestię uzasadniania), że p" 
oraz kontekście domniemanego podmiotu wiedzy (podmiotu o określonych zapatrywaniach dotyczących kwestii uzasadniania przekonań w momencie $t_{1}$ ), nawet kiedy podmiot przypisujący wiedzę oraz podmiot, któremu wiedza jest przypisywana, są jedną i tą samą osobą. Z takiego typu sytuacją mamy do czynienia $\mathrm{w}$ rozważanym przykładzie; osoba $\mathrm{B}$ ocenia swoją wiedzę $\mathrm{w}$ momencie przed podwyższeniem standardów epistemicznych i dochodzi do wniosku, że nastawienie sądzeniowe $\mathrm{z}$ tego momentu (z początku rozmowy) nie powinno zostać zaklasyfikowane jako wiedza z punktu widzenia kontekstu o wyższych standardach epistemicznych (po wspomnieniu hipotezy, że zaobserwowane zwierzę to pomalowany w paski muł). Wypowiedzenie pierwszego zdania analizowanego dialogu („Nie, wiedziałem wówczas, że to jest zebra”) jest niewłaściwe, skoro osoba przypisująca sobie wiedzę zmieniła zapatrywania na kwestię uzasadnienia przekonania, że zaobserwowane zwierzę to zebra, co doprowadziło do istotnych różnic pomiędzy parametrami kontekstu podmiotu przypisującego wiedzę oraz domniemanego podmiotu wiedzy.

Druga strategia odpowiedzi na trudności wyłaniające się w związku z przykładem, który zaprezentował Palle Yourgrau, wydaje się zatem o wiele bardziej obiecująca niż pierwsza, chociaż w związku z nią także wyłaniają się pewne wątpliwości. Rozstrzygnięcia wymaga przede wszystkim pytanie, czy przedostatnie zdanie wypowiedziane przez osobę B jest niewłaściwe z punktu widzenia zasad pragmatyki (na przykład nie stosuje się do maksym konwersacyjnych), czy jest po prostu fałszywe. Nawet kiedy kontekstualista przychyla się do przyjęcia drugiej z wymienionych możliwości, istnieje podstawa do zakwestionowania spójności takiego poglądu z zajmowanym stanowiskiem teoretycznym. Czy kontekstualista nie jest zobowiązany do uznania, że podmiot dysponował wiedzą ze względu na niższe standardy epistemiczne obowiązujące na początku rozmowy, czyli wypowiedzenie zdania „Wiedziałem wówczas, że to jest zebra” jest prawdziwe? $\mathrm{Na}$ kontekstualiście spoczywa zatem ciężar rozstrzygnięcia szczegółowych zagadnień pojawiających się z drugą strategią.

\section{Trzeci zarzut przeciw konktestualizmowi}

Jednak nawet kiedy kontekstualista wyjdzie zwycięsko z drugiej próby, której zostało poddane jego stanowisko teoretyczne, musi odpowiedzieć na przedstawiony przez Ernesta Sosę zarzut zupełnie innej natury, podważający tezę głoszącą 
przydatność kontekstualizmu w celu udzielenia odpowiedzi na ważne pytania epistemologiczne ${ }^{8}$. Punktem wyjścia argumentu Sosy jest dokonanie porównania pomiędzy słowem „wiedzieć” a wyrażeniami, których wrażliwość kontekstowa nie budzi kontrowersji. Do takich wyrażeń należą wyrażenia zaliczane do podstawowego zestawu wyrażeń okazjonalnych (na przykład zaimek osobowy ,ja” lub zaimek wskazujący „to”). Kolejną grupą wyrażeń o znaczeniu zależnym od zmian kontekstu są wyrażenia wieloznaczne (takie jak słowo „zamek”) ciwa ocena argumentu Sosy wymaga zbadania, jak daleko sięga podobieństwo pomiędzy wyrażeniami należącymi do obu wymienionych zbiorów oraz słowem „wiedzieć”.

Zacznijmy od bliższego przyjrzenia się porównaniu z wyrażeniami okazjonalnymi, które stanowią centralny temat Demonstratives Kaplana. W pracy Kaplana zostaje wyróżniony charakter wyrażenia i treść wyrażenia, przy czym charakter to funkcja $\mathrm{z}$ kontekstu do treści wyrażenia, a treść to funkcja z okoliczności oceny do ekstensji. Na przykład w wypadku wyrażenia okazjonalnego ,ja” charakter wyrażenia wyznacza odniesienie danego wypowiedzenia, którym każdorazowo jest osoba dokonująca wypowiedzenia. Słowu „wiedzieć” także można przypisać określony charakter, a mianowicie wybieranie sądów stanowiących przedmiot przekonań danego podmiotu spełniających warunek prawdziwości. Dodatkowym warunkiem wymagającym spełnienia i wyznaczonym przez charakter słowa „wiedzieć” jest znajdowanie się przez podmiot w odpowiednio dobrej pozycji epistemicznej względem tych prawdziwych sądów. Siła pozycji epistemicznej podmiotu może zostać uznana za odpowiednio dobrą, żeby dane przekonanie zostało zaklasyfikowane jako wiedza w pewnych okolicznościach oceny wypowiedzenia zdania przypisującego wiedzę, a nie wystarczać do zaliczenia nasta-

E. Sosa, Skepticism and Contextualism, „Philosophical Issues” 2000, Vol. 10. Do tych ważnych problemów epistemologicznych, które można próbować rozwiązać na gruncie kontekstualizmu należą między innymi: zagadnienie sceptycyzmu, problem Gettiera czy przykład loterii.

9 Rafał Palczewski w artykule $O$ wrażliwości kontekstowej zdań typu „S wie, że p” obok okazjonalności i wieloznaczności wymienia inne własności semantyczne, które mogą być odpowiedzialne za wrażliwość kontekstową zdań przypisujących wiedzę: nieostrość i eliptyczność (R. Palczewski, O wrażliwości kontekstowej zdań typu „S wie, że p”, „Analiza i Egzystencja” 2005, nr 2, s. 135-137) Te dodatkowe własności zostały pominięte w niniejszej pracy z dwóch powodów:

1) Sosa nie odnosi się do nich, formułując swój zarzut wymierzony względem kontekstualizmu.

2) w moim przekonaniu okazjonalność i wieloznaczność to o wiele bardziej przekonujące kandydatury (można wskazać więcej cech wspólnych łączących wyrażenia, którym bezspornie przysługują te własności, z operatorem wiedzy). 
wienia sądzeniowego do takiej kategorii w innych okolicznościach, o wyższych standardach epistemicznych ${ }^{10}$.

Wspólne cechy wyrażeń wieloznacznych oraz słowa „wiedzieć” są dużo trudniejsze do wskazania i ograniczają się właściwie do ogólnej konstatacji, że wraz ze zmianą kontekstu użycia wyrażenia zmienia się treść tego wyrażenia ${ }^{11}$. W wypadku wyrażeń wieloznacznych zmiana znaczenia ma jednak o wiele bardziej ewidentny charakter i powinna zostać w jednoznaczny dla odbiorcy sposób zasygnalizowana przez nadawcę wypowiedzenia. Kiedy zostaje wypowiedziane zdanie przypisujące wiedzę, sytuacja wygląda odmiennie, ponieważ intencja nadawcy wypowiedzenia nie jest czynnikiem decydującym (albo przynajmniej nie jest jedynym czynnikiem decydującym), jakie standardy epistemiczne obowiązują w kontekście rozmowy ${ }^{12}$.

10 Brian Weatherson w artykule Questioning Contextualism argumentuje, że istnieje znacząca różnica pomiędzy operatorem wiedzy a wyrażeniami okazjonalnymi w wąskim rozumieniu (wyrażeniami $\mathrm{z}$ listy Kaplana) polegająca na spełnianiu przez pytania zawierające te ostatnie - w przeciwieństwie do słowa „wiedzieć” - czterech własności: mówcy, wyjaśnienia, różnych odpowiedzi, przeczącej zgody. I tak na przykład w wypadku pytania zawierającego słowo „tutaj” z listy Kaplana „Czy jest tutaj Moriarty?” skierowanego przez Watsona, który przebywa na przyjęciu w Liverpoolu, do Holmesa śledzącego Moriarty’ego przez satelitę te cztery własności zostają objaśnione następująco:

MÓWCA: Odpowiedź na pytanie zależy od kontekstu Watsona, to znaczy jest twierdząca wówczas, gdy Moriarty jest wraz z Watsonem na przyjęciu w Liverpoolu, a przecząca, gdy Moriarty znajduje się gdzie indziej.

WYJAŚNIENIE: W niektórych kontekstach jest dopuszczalne zadanie przez Holmesa dodatkowego pytania w celu uzyskania odpowiednich informacji dotyczących okoliczności, w których znajduje się Watson (na przykład pytania „Gdzie jesteś?”).

RÓŻNE ODPOWIEDZI: Gdyby pytanie „Czy jest tutaj Moriarty?” skierowała do Holmesa osoba, która znajduje się w innym miejscu niż Watson, Holmes udzieliłby tej osobie innej odpowiedzi niż Watsonowi (gdyby odpowiedział Watsonowi twierdząco, tej innej osobie odpowiedziałby przecząco).

PRZECZĄCA ZGODA: Istnieje możliwość udzielenia spójnej odpowiedzi poprzez zaprzeczenie, które polega na powtórzeniu wyjściowego pytania po partykule „nie” z odpowiednią zmianą szyku słów („Nie, Moriarty jest tutaj”).

11 Warto przy okazji odnotować, że kontekstualizm i koncepcja wieloznaczności niesystematycznej to dwa różne, niewykluczające się stanowiska.

12 Arnold Zwicky i Jerrold Sadock w tekście Ambiguity Tests and How to Fail Them przedstawiają różnorakie testy pozwalające określić, czy dane wyrażenie jest wieloznaczne (A. Zwicky, J. Sadock, Ambiguity Tests and How to Fail Them, w: Syntax and Semantics, ed. J. Kimball, Vol. 4, New York Academic Press, New York 1975). Niektóre z tych testów bardzo przypominają zaproponowane przez Hermana Cappellena i Ernesta Lepore’a testy na okazjonalność. Jednak zastosowanie zarówno pierwszego, jak i drugiego rodzaju testów nie daje jednoznacznych rezultatów, ponieważ w zależności od wybranego przykładu zdania przypisującego wiedzę można argu- 
Obok kwestii semantycznych, które wyłaniają się na gruncie kontekstulizmu, odpowiedzi wymaga pytanie, czy przyjęcie takiej teorii w kwestii funkcjonowania słowa „wiedzieć” umożliwia bardziej dogłębne spojrzenie na podstawowe problemy epistemologiczne. Odpowiedź na to pytanie udzielona przez autora Skepticism and Contextualism jest przecząca: epistemologów interesują bowiem

mentować, że przechodzą z pozytywnym rezultatem testy jednego typu, drugiego typu bądź też obu rodzajów jednocześnie (chociaż przeciwnicy kontekstualizmu często twierdzą, że operatora wiedzy wcale nie można zaklasyfikować na podstawie zaproponowanych testów jako wyrażenia wrażliwego kontekstowo, a ponieważ spór dotyczy intuicji wywołanych przez konkretne przykłady, wydaje się, że nie dysponujemy kryterium niezależnym od naszych predylekcji teoretycznych pozwalającym stwierdzić, która ze stron ma rację).

Ograniczmy się do przywołania jednego testu, czyli testu redukcji, którego zastosowanie służy stwierdzeniu, czy dane wyrażenie jest wieloznaczne (test ten jest bardzo podobny do testu tworzenia wspólnych opisów zaproponowanego przez Cappellena i Lepore’a, jednak dokonanie szczegółowego porównania tych testów wykracza poza ramy tej pracy). Test redukcji polega na sprawdzeniu, czy w zdaniu utworzonym za pomocą koniunkcji trzeba powtórzyć badane wyrażenie w celu zachowania pierwotnego sensu zdań wyjściowych (w przeciwnym razie otrzymujemy albo zdanie zeugmatyczne, albo różne znaczenia tego wyrażenia w zdaniach wyjściowych zostają ujednolicone). Przyjrzyjmy się konkretnym przykładom:

1) Powstanie zeugmy: połączenie za pomocą koniunkcji zdań „Bal jest spróchniały” oraz „Bal jest uroczysty” prowadzi do brzmiącego absurdalnie zdania „Bal jest spróchniały i uroczysty”.

2) Ujednolicenie znaczenia: koniunkcję zdań „Żony uczestników insurekcji Kościuszkowskiej przechowują kosy” oraz „Żony mieszkańców wsi Głuchowo przechowują kosy” interpretujemy w taki sposób, że słowo „kosy” odnosi się w zdaniu „Żony uczestników insurekcji Kościuszkowskiej oraz żony mieszkańców wsi Głuchowo przechowują kosy” do kos-narzędzi rolniczych, mimo że we wsi Głuchowo jedyne kosy to ptaki, ponieważ jest to wieś zamieszkała wyłącznie przez ornitologów.

Jak wygląda zastosowanie tego testu do zdań zawierających operator wiedzy? W niektórych wypadkach nie ma podstawy do zaklasyfikowania tych zdań jako wieloznacznych, jak zauważa Rafał Palczewski, posługując się przykładem zdania „Robert wie, że prawo sylogizmu hipotetycznego jest tautologią klasycznego rachunku zdań oraz że Ania była wczoraj w kinie” - powstałego poprzez połączenia za pomocą koniunkcji zdania „Robert wie, że prawo sylogizmu hipotetycznego jest tautologią klasycznego rachunku zdań” oraz zdania „Robert wie, że Ania była wczoraj w kinie" (R. Palczewski, Wiedza w kontekstach. W obronie kontesktualizmu epistemicznego, tom I, dz. cyt., s. 380) W innych wypadkach wyniki są bardziej niejednoznaczne: czy na przykład wypowiedziane przez jakąś osobę podczas dochodzenia policyjnego zdanie „Państwo Kowalscy i państwo Wiśniewscy wiedzą, że Piotr był we wtorek w pracy” przyjmuje jednolite znaczenie związane z operowaniem bardziej restrykcyjnym pojęciem wiedzy (ze względu na obowiązujące w kontekście śledztwa wysokie standardy epistemiczne), chociaż państwo Kowalscy widzieli jedynie kapelusz Piotra wiszący w korytarzu, natomiast państwo Wiśniewscy widzieli samego Piotra urzędującego w swoim biurze? Oczywiście w tym wypadku można byłoby argumentować, że wypowiedziane podczas śledztwa utworzone za pomocą koniunkcji zdanie jest po prostu fałszywe (co przechylałoby szalę zwycięstwa na korzyść własności okazjonalności). Sytuacja jednak nie jest w tym wypadku jasna. 
wypadki przypisania wiedzy dokonywane w kontekstach o wysokich (względnie: najwyższych) standardach epistemicznych, które stanowią jedynie pewien podzbiór przykładów analizowanych przez kontekstualistów. Mimo że opracowanie adekwatnej teorii semantyki operatora wiedzy uwzględniającej aspekt kontekstowej zależności oraz kwestia aplikacji tej teorii w dziedzinie epistemologii to dwa odrębne zagadnienia, jednak pozostają ze sobą we wzajemnej zależności wbrew mylącym pozorom, za które odpowiadają sami przedstawiciele kontekstualizmu epistemicznego. Lektura tekstów najbardziej znanych obrońców kontekstowej zależności słowa „wiedzieć” może w niektórych wypadkach prowadzić do wniosku, że dopracowanie kwestii semantycznych odgrywa drugorzędną rolę, ponieważ nie wpływa na doniosłość nurtu kontekstualistycznego jako dostarczającego świeżej i płodnej perspektywy na rozważane od stuleci problemy epistemologiczne. Takiemu podejściu czasem towarzyszy pogląd, że nie jest ważne (z punktu widzenia epistemologii), jaką teorię kontekstualistyczną przyjmiemy, o ile tylko uwzględnimy aspekt zmiany treści słowa „wiedzieć” wraz z odpowiednimi zmianami parametrów kontekstu. Wydaje się jednak, że ustalenie, jak wygląda mechanizm semantyczny odpowiadający za kontekstową zależność operatora wiedzy, odgrywa niebagatelne znaczenie. Gdyby słowo „wiedzieć” należało na przykład zaliczyć do kategorii wyrażeń, które mają więcej cech wspólnych z wyrażeniami wieloznacznymi niż wyrażeniami okazjonalnymi, wypadałoby uznać, że intencja nadawcy wypowiedzenia przypisującego wiedzę decyduje, z jakim znaczeniem mamy w danym wypadku do czynienia. O ile założymy przy tym, że nadawca nie jest skrępowany jakimiś niezależnymi „zewnętrznymi” normami, przypisywanie komuś wiedzy podlega znacznej subiektywizacji. Posłużmy się przykładem. Osoba wypowiadająca zdanie „Zamek jest zniszczony” nie jest skrępowana żadnymi zewnętrznymi kryteriami określającymi, czy słowo „zamek” odnosi się do zamku-budowli, czy do zamku-mechanizmu umożliwiającego otwieranie i zamykanie drzwi. Kiedy nawet kontekst konwersacyjny wskazuje, że chodzi o zamek-budowlę (na przykład w trakcie zwiedzania ruin średniowiecznego zamku), nadawca wypowiedzenia nadal może sprostować, że wypowiedział zdanie „Zamek jest zniszczony”, myśląc o zamku w drzwiach w swoim mieszkaniu. Wprawdzie takie wypowiedzenie jest niewątpliwie niewłaściwe z pragmatycznego punktu widzenia, ale nadawca może podać wyjaśnienie takiego zwrotu w rozmowie, chociażby za pomocą następujących słów: „Zniszczony średniowieczny zamek nasunął mi myśl, że także zamek w drzwiach w moim mieszka- 
niu jest zniszczony. Już dawno miałem go wymienić i teraz znowu sobie o tym przypomniałem". Czy przykład pragmatycznie niewłaściwego wypowiedzenia słowa „wiedzieć” (założywszy, że semantyka tego słowa pozwala zaklasyfikować je do wspólnej kategorii z wyrażeniami wieloznacznymi) znajduje analogiczne, przekonujące rozwinięcie? Zmodyfikowana wersja przykładu z lotniskiem wydaje się sugerować, że nie:

Maria zainteresowana zakupem perfum na lotnisku rozmawia z Małgorzatą mającą w planach ważne spotkanie biznesowe w Chicago. Cała rozmowa dotyczy znanych rozmówczyniom wypadków zmiany planu lotów ze względu na różne nieprzewidziane okoliczności oraz zdarzających się błędów w rozdawanych pasażerom wydrukom wyszczególniającym miejsca międzylądowań. Małgorzata stwierdza między innymi: „Rozkład lotów może zawierać błąd. Smith nie wie, że samolot będzie miał międzylądowanie w Chicago", na co Maria odpowiada "A jednak Smith wie, że samolot będzie miał międzylądowanie w Chicago".

Nawet kiedy Maria doda: „Z mojego punktu widzenia wydaje się oczywiste, że Smith wie, że samolot będzie miał międzylądowanie w Chicago. Chodzi przecież tylko o zakup perfum", dokonane wcześniej wypowiedzenie wcale nie uzyskuje odpowiedniego wyjaśnienia. Może to wskazywać, że to wypowiedzenie jest nie tylko pragmatycznie niewłaściwe, ale po prostu fałszywe.

Inaczej wyglądałaby sytuacja, gdybyśmy uznali, że semantyka słowa „wiedzieć" wygląda podobnie do takich zależnych kontekstowo przymiotników jak przymiotnik „wysoki”, co pozwalałoby zaklasyfikować operator wiedzy do innej kategorii wyrażeń niż wyrażenia wieloznaczne. Trafne przypisanie jakiemuś przedmiotowi własności bycia wysokim wymaga porównania tego przedmiotu z określonym zbiorem przedmiotów wyznaczonym przez kontekst. Na przykład trener koszykówki może przypisać inną wartość logiczną wypowiedzeniu „Jan Kowalski jest wysoki” niż wychowawca klasy IIIa. Trener koszykówki poszukujący członków drużyny operuje dużo wyższymi standardami bycia wysokim (zbiór przedmiotów, z którymi zestawia daną osobę, to gracze w koszykówkę) niż wychowawca klasy IIIa porównujący Jana z pozostałymi podopiecznymi (Jan może być najwyższą osobą w klasie, a mimo to nie nadawać się na gracza w koszykówkę z powodu zbyt niskiego wzrostu).

Podobieństwo pomiędzy słowem „wiedzieć” a słowem „wysoki” jest szczególnie widoczne, kiedy weźmiemy pod uwagę kontekstualistyczną teorię istotnych możliwości, na przykład w wersji przedstawionej przez Davida Lewisa. Zgodnie 
$\mathrm{z}$ tą teorią uznanie zdania przypisującego wiedzę za prawdziwe wymaga wykluczenia przez świadectwo domniemanego podmiotu wiedzy wszystkich relewantnych alternatywnych scenariuszy (często o charakterze sceptyckim) ${ }^{13}$. Ponieważ kontekst wyznacza, którym scenariuszom przysługuje własność istotności, może się tak zdarzyć, że oceniając prawdziwość konkretnego zdania o postaci „S wie, że $p$ ” w jednym kontekście ewaluacji bierzemy pod uwagę pewien alternatywny scenariusz, a w innym nie.

Jednak podobieństwa pomiędzy semantyką słowa wiedzieć a semantyką słowa „wysoki” nie ograniczają się jedynie do wyznaczenia przez kontekst odpowiednich klas przedmiotów (w pierwszym wypadku) lub scenariuszy (w drugim wypadku) stanowiących odpowiednią podstawę dokonania porównania. Podczas gdy standardy dla uznania jakiegoś przedmiotu za wysoki są w pewnych kontekstach wyższe niż w innych, standardy dla uznania danego zdania przypisującego wiedzę za prawdziwe są bardziej wymagające w wybranych sytuacjach wymagających wyeliminowania większej liczby alternatywnych scenariuszy. Trzeba też zauważyć, że parametr, na który wywiera wpływ liczba wyeliminowanych scenariuszy, czyli stopień uzasadnienia przekonania, pozostaje stały niezależnie od tego, w jakim kontekście dokonujemy ewaluacji wartości logicznej danego zdania o postaci „S wie, że $p$ ”. Analogicznie: o tym, czy dana osoba jest wysoka, decyduje to, ile ma centymetrów wzrostu (im więcej centymetrów mierzy, tym jest wyższa, nawet kiedy nie możemy określić tej osoby mianem „wysokiej” ze względu na klasę porównawczą obowiązującą w danym kontekście).

W wypadku przymiotnika „wysoki” intencja nadawcy wypowiedzenia nie jest czynnikiem decydującym o jego wartości logicznej - należy także wziąć pod uwagę inne aspekty kontekstu. Posłużmy się przykładem, żeby zilustrować tę własność badanego wyrażenia (którą podziela, jak wskazują wcześniejsze wywody, ze słowem „wiedzieć”):

Trener koszykówki: Poszukuję zawodników do mojej drużyny.

Wychowawca klasy IIIa: Wielu moich podopiecznych lubi grać w koszykówkę.

Trener koszykówki: Zawodnicy powinni odznaczać się wysokim wzrostem.

13 Definicja podana przez Lewisa jest następująca: „S wie, że $p$ wtedy i tylko wtedy, gdy świadectwo $S$-a eliminuje każdą możliwość, w której nie- $p$ - pst! - oprócz tych możliwości, które w uprawniony sposób ignorujemy" (D. Lewis, Elusive Knowledge, w: Skepticism. A Contemporary Reader, eds. K. DeRose, T.A. Warfield, Oxford University Press, Oxford 1999, s. 225). Ponieważ w powyższej definicji występuje słowo „każdy”, kontekstowa wrażliwość słowa „wiedzieć” ma podobny charakter do zależności kontekstowej zwrotów kwantyfikujących. 
Wychowawca klasy IIIa: Jan Kowalski jest wysoki. To najwyższy uczeń w mojej klasie.

Trener koszykówki: Ile centymetrów wzrostu ma Jan Kowalski? Wychowawca klasy IIIa: Jan jest mniej więcej mojego wzrostu.

Trener koszykówki: W takim razie Jan nie jest wysoki. Gracze w koszykówkę są przynajmniej o pół głowy wyżsi.

Wychowawca klasy IIIa: Nie zgadzam się z tobą. Jan Kowalski jest wysoki. To najwyższy uczeń w mojej klasie.

Ostatnie wypowiedzenie dokonane przez wychowawcę klasy IIIa jest niewłaściwe. Wyjaśnienie tej niewłaściwości może się odwoływać do czynników pragmatycznych (wtedy zdanie „Jan Kowalski jest wysoki” oceniamy jako prawdziwe) albo semantycznych, kiedy uznamy, że sąd wyrażany przez zdanie przypisujące Janowi własność bycia wysokim jest fałszywy. Ponieważ manewr polegający na wyraźnym wskazaniu przez nadawcę wypowiedzenia towarzyszącej intencji, czyli dokonanie porównania z konkretnym zbiorem przedmiotów („To najwyższy uczeń w mojej klasie”), nie przynosi oczekiwanych skutków (takimi skutkami byłoby skłonienie rozmówcy do uznania prawdziwości wypowiedzenia „Jan Kowalski jest wysoki”), wypada raczej uznać, że dokonane przez wychowawcę klasy IIIa wypowiedzenie jest wadliwe nie tylko ze względów pragmatycznych, lecz także semantycznych.

Przeprowadzone rozważania pozwalają nam powrócić do kwestii wpływu mechanizmów semantycznych odpowiedzialnych za funkcjonowanie operatora wiedzy na wymagające rozstrzygnięcia pytania epistemologiczne. Gdyby semantyka słowa „wiedzieć” wyglądała tak jak w wypadku wyrażeń wieloznacznych kwestia przypisania danemu podmiotowi wiedzy, podlegałaby - na co zwróciliśmy uwagę uprzednio - znacznej subiektywizacji. W takim wypadku teoria kontekstualistyczna nie byłaby interesująca dla epistemologa, którego interesuje wiedza per se, a nie - intencje użytkowników języka posługujących się słowem „wiedzieć”. Inaczej wygląda sprawa z zestawieniem operatora wiedzy z takim zależnym kontekstowo przymiotnikiem jak „wysoki” i przyjęciu, że pomiędzy semantyką tych wyrażeń istnieją znaczące podobieństwa. O ile tak jest, prawomocnym użyciem słowa „wiedzieć” rządzą normy niezależne od podmiotu dokonującego wypowiedzenia, a wyznaczone przez szeroko rozumiany kontekst. Oczywiście nawet wtedy nie można powiedzieć, że obowiązuje jeden niezmienny i maksymalnie wysoki standard dla wiedzy, który jest interesujący z punktu wi- 
dzenia epistemologa. Ale czegoś takiego nie chcemy chyba powiedzieć, ponieważ byłaby to droga prowadząca ku sceptycyzmowi (maksymalnie wysoki standard wymagałby wyeliminowania wszystkich alternatywnych scenariuszy, co jest praktycznie niemożliwe $)^{14}$. Przyjęcie sceptycyzmu byłoby podobne, uciekając się znowu do analogii ze słowem „wysoki”, do tak znacznego rozszerzenia zbioru alternatywnych możliwości, że przestają być w ogóle interesujące (jakbyśmy rozszerzyli zbiór przedmiotów, z którymi porównujemy Jana, zastanawiając się nad wartością logiczną zdania „Jan jest wysoki”, żeby obejmował nie tylko ludzi, ale także góry i wieżowce).

Sosa nie przykłada wiele wagi do istotnych różnic pomiędzy poszczególnymi wersjami teorii kontekstualistycznej określonych ze względu na odmienny punkt zapatrywania na semantykę operatora wiedzy. Mimo to da się zauważyć przekonanie o ścisłym związku pomiędzy kwestiami semantycznymi a kwestiami epistemologicznymi. Uznanie istnienia istotnych podobieństw pomiędzy słowem „wiedzieć” a wyrażeniami zaliczanymi do podstawowego zestawu wyrażeń okazjonalnych lub wyrażeniami wieloznacznymi może oznaczać, że studiowanie przykładów wypowiedzeń zdań przypisujących wiedzę, które oceniane są jako prawdziwe z punktu widzenia codziennych kontekstów o niskich standardach epistemicznych, może nic nie wnosić do badań epistemologa biorącego pod uwagę konteksty o wysokich standardach epistemicznych - podobnie jak bez znaczenia dla odpowiedzi na postawione przez Jana pytanie „Czy byłem wczoraj w ki-

14 Michael Blome-Tillmann zwraca uwagę, że zarówno David Lewis, jak Ernest Sosa przyjmują, że w kontekście rozważań epistemologicznych obowiązuje kontekst sceptycki (zakładamy maksymalnie wysoki standard dla wiedzy). W wypadku przedstawiciela teorii relewantnych alternatyw takie stanowisko wiąże się z przyjęciem „reguły uwagi”, która głosi, że jeśli osoby mówiące w kontekście $C$ zwracają uwagę na możliwość $w$, wówczas $w$ nie może zostać w uprawniony sposób zignorowana w $C$. Ponieważ w wypadku teoretycznych rozważań nad pojęciem wiedzy hipotezy sceptyczne zawsze stanowią tło prowadzonych rozważań, Blome-Tillman formułuje konkurencyjną względem „reguły uwagi” - „regułę presupozycji konwersacyjnej”:

(RPK) Jeśli $w$ jest niekompatybilna $\mathrm{z}$ konwersacyjnymi presupozycjami osób mówiących w $C$, wówczas może zostać $\mathrm{w}$ uprawniony sposób zignorowana w $C$ (o ile reguła inna niż (RPK) nie stwierdza, że $w$ nie może zostać w uprawniony sposób zignorowana $\mathrm{w} C$ ) (M. Blome-Tillmann, Contextualism and the Epistemological Enterprise, „Proceeding of the Aristotelian Society" 2007, Vol. 107, No. 3, s. 393).

W wypadku, gdy filozof podziela zazwyczaj przyjmowane w codziennych kontekstach presupozycje (takie jak presupozycja, że nie jesteśmy pozbawionymi rąk mózgami w naczyniu), sceptycyzm nie jest nieuchronnym wynikiem, do jakiego prowadzi zajmowanie się zagadnieniami epistemologicznymi. 
nie?” jest dokonane przez Piotra wypowiedzenie „Byłem wczoraj w kinie” (bądź wypowiedzenie wskazującego wnętrze swojej szafy na ubrania Piotra „Wszystkie zamki są zniszczone" jako reakcja na chęć dowiedzenia się przez Jana, czy wiele zamków obronnych jest zniszczonych). Dociekania filozoficzne takie jak próba określenia natury, warunków i zakresu ludzkiej wiedzy nie odnoszą korzyści, jak sugeruje Sosa, z badania teoretycznych podstaw kontekstualizmu. Osoby formułujące teorie epistemologiczne posługują się innym pojęciem wiedzy niż użytkownicy języka znajdujące się w codziennych sytuacjach. Autor Skepticism and Contextualism zauważa wprawdzie, że słowo „wiedzieć” pod pewnymi względami bardziej przypomina takie zależne kontekstowo przymiotniki jak „wysoki” niż wyrażenia z podstawowego zestawu wyrażeń okazjonalnych oraz wyrażenia wieloznaczne, ponieważ aspekty brane pod uwagę przy określeniu znaczenia słowa „wiedzieć” (na przykład aspekt związany z uzasadnieniem przekonania) nie zmieniają się wraz ze zmianą kontekstu, jednak nie wpływa to na zasadniczą diagnozę dotyczącą braku przydatności kontekstualizmu w celu rozstrzygnięcia podstawowych pytań epistemologicznych.

Zarzut sformułowany przez Sosę stawia kontekstualistę w niekorzystnej sytuacji o tyle, że kontekstualista zwraca właśnie uwagę na cechy wspólne wyrażeń zaliczanych do podstawowego zestawu wyrażeń okazjonalnych oraz innych wyrażeń, których kontekstowa zależność stanowi przedmiot sporu z inwariantystami, a eksponowanie różnic pomiędzy tymi grupami wyrażeń oznacza (a przynajmniej tak może być postrzegane) podcinanie korzeni własnej teorii oraz skłanianie się w kierunku teorii uznawanej przez oponentów. Jednak sformułowana właśnie trudność mająca wzmocnić zarzut skierowany przeciwko kontekstualizmowi nie ma decydującego charakteru i może zostać odparta poprzez wyróżnienie rozmaitych kategorii wyrażeń zależnych od zmian kontekstu, które mają wprawdzie pewne cechy wspólne, ale których funkcjonowanie wiąże się $\mathrm{z}$ różnego rodzaju mechanizmami semantycznymi. Co więcej należy zauważyć, powracając do meritum argumentu Sosy, że opinia dotycząca nieprzydatności kontekstualizmu w celu określenia natury, warunków i zakresu ludzkiej wiedzy nie została należycie uzasadniona. Dlaczego by nie przyjąć, że natura wiedzy wygląda w taki sposób, w jaki przedstawiają tę kwestię kontekstualiści, czyli że nie istnieje jeden zestaw standardów epistemicznych powszechnie obowiązujący, lecz podlegają one zróżnicowaniu w zależności od kontekstu? Dlaczego nie przyjąć, że stopień, w jakim muszą zostać spełnione warunki nałożone na wiedzę (na przykład zawsze jest brana pod uwagę siła pozycji epistemicznej podmiotu 
względem danego sądu, ale wymagany stopień tej siły jest rzeczą zmienną), zależy od okoliczności wypowiedzenia zdania przypisującego wiedzę? Dlaczego nie uznać, że zakres ludzkiej wiedzy zależy od pojęcia wiedzy, którym się posługujemy? Argument Sosy zdaje się raczej zakładać, że inwariantyzm jest słusznym teoretycznym ujęciem semantyki słowa „wiedzieć”, niż dostarczać racji dla przyjęcia takiego poglądu. Kontekstualista znajduje zatem także odpowiedź (nawet jeśli nie jest to odpowiedź $\mathrm{w}$ pełni satysfakcjonująca $\mathrm{z}$ punktu widzenia inwariantysty) na trzeci z przedstawionych zarzutów.

\section{Zakończenie}

Jakie wnioski podsumowujące można wyciągnąć z zestawienia trzech zrekonstruowanych i omówionych argumentów wymierzonych przeciwko kontekstualizmowi? Podejmując próbę odpowiedzi z punktu widzenia teorii kontekstualistycznej, starałam się pokazać, że żaden z tych argumentów nie ma decydującego charakteru, czyli że kontekstualista znajduje odpowiedź pozwalającą obronić zajmowane stanowisko, nawet kiedy ( $\mathrm{w}$ wypadku drugiego $\mathrm{z}$ przedstawionych argumentów) nie jest to odpowiedź w pełni przekonująca.

Zarzut przedstawiony przez Sosę, odbiegający charakterem od dwóch poprzednich, budzi najwięcej wątpliwości (wspiera się między innymi na przyjęciu podobieństwa in extenso pomiędzy semantyką wyrażeń okazjonalnych z zestawu podstawowego a semantyką słowa „wiedzieć”, co nie jest uprawnionym założeniem). Charakter tego zarzutu jest odmienny między innymi dlatego, że ściśle wiąże się z funkcjonowaniem słowa „wiedzieć” i nie znajduje prostego przełożenia na funkcjonowanie innego rodzaju wyrażeń uznawanych za wrażliwe kontekstowo. Wprawdzie analogiczny zarzut można sformułować, jak zauważa Sosa, w odniesieniu do pojęć etycznych takich jak pojęcie szczęścia, ale sytuacja jest moim zdaniem asymetryczna, ponieważ nawet przez moment nie wydaje się rozsądne, że przyjmując kontekstową zależność słowa „szczęśliwy”, odpowiadamy na centralne pytania etyki (czy potrafimy znaleźć jakąkolwiek wspólną cechę charakteryzującą wszystkich ludzi określanych mianem „szczęśliwy”?), natomiast teoria kontekstualistyczna pozwala dostrzec pewne aspekty wiedzy, które nie zostały w pełni wyeksponowane przed sformułowaniem tej teorii (wspólna cecha przysługująca wszystkim wypadkom uzasadnionego przypisania wiedzy to odpowiednio silna pozycja epistemiczna podmiotu, któremu przypisujemy 
wiedzę, natomiast obowiązujące standardy epistemiczne są wyznaczone przez kontekst osoby przypisującej wiedzę) ${ }^{15}$.

Odmienne miejsce zajmuje pierwszy z przedstawionych argumentów, ponieważ podobne trudności można wskazać w odniesieniu do innych rodzajów wyrażeń (przywołany został tekst Richarda, wychodzący od rozważenia wypadku sporu dotyczącego wartości logicznej zdania przypisującego danemu podmiotowi własność bycia bogatym). Jeśli chodzi o argument drugi - to także i w tym wypadku odnajdujemy stosowną analogię poprzez przedstawienie przez DeRose’a dialogu, w którym użyte zostaje kontekstowo zależne słowo „możliwy”"16. Konkluzja nasuwająca się w świetle przeprowadzonego podziału argumentów przeciwko kontekstualizmowi (na argumenty specyficzne dla słowa „wiedzieć” oraz argumenty podzielane przez inne wyrażenia uznawane za zależne od zmian kontekstu) polega na zauważenia trudności, w obliczu których stoi kontekstualizm epistemiczny (podobnie jak inne rodzaje kontekstualizmu) przy jednoczesnym uznaniu, że teoria ta rzuca nowe światło na sięgające swoimi korzeniami antyku pytania epistemologiczne stawiane przez filozofów.

\section{Bibliografia}

Bach, K., The Emperor's New 'Knows', w: Contextualism in Philosophy. Knowledge, Meaning and Truth, eds. G. Preyer, G. Peter, Oxford University Press, Oxford 2005, s. 51-90.

Blome-Tillmann M., Contextualism and the Epistemological Enterprise, „Proceeding of the Aristotelian Society" 2007, Vol. 107, No. 3, s. 387-394.

Cappelen H., Lepore E., Insensitive Semantics: A Defense of Semantic Minimalism and Speech Act Pluralism, Oxford, Blackwell 2005.

Cohen S., Ascriber Contextualism, w: The Oxford Handbook of Skepticism, ed. J. Greco, Oxford University Press, Oxford 2008, s. 415-434.

15 Kant twierdził, że pojęcie szczęścia jest pojęciem empirycznym, ponieważ wyprowadzane jest $\mathrm{z}$ doświadczenia, co sprowadzałoby dociekania kontekstualistów nad tym pojęciem do przeprowadzenia badania, w jaki sposób ludzie używają tego pojęcia. Pojęcie wiedzy jest natomiast innego rodzaju pojęciem, a kontekstualizm pomaga lepiej uchwycić aporie, które ze sobą niesie, zwłaszcza w odniesieniu do problemu sceptycyzmu.

16 K. DeRose, The Case for Contextualism: Knowledge, Skepicism and Context, Vol. 1, Oxford University Press, Oxford 2009, s. 205. 
Cohen S., Contextualism, Skepticism, and the Structure of Reasons, „Philosophical Perspectives" 1999, Vol. 13, s. 57-89.

Cohen S., Knowledge and Context, „The Journal of Philosophy” 1986, Vol. 83, No. 10, s. 574-583.

DeRose K., Solving the Skeptical Problem, w: Skepticism. A Contemporary Reader, eds. K. DeRose, T.A. Warfield, Oxford University Press, Oxford 1999, s. 183-219.

DeRose K., The Case for Contextualism: Knowledge, Skepicism and Context, Vol. 1, Oxford University Press, Oxford 2009.

Dretske F., Epistemic Operators, w: Skepticism. A Contemporary Reader, eds. K. DeRose, T.A. Warfield, Oxford University Press, Oxford 1999, s. 131-144.

Feldman, R., Contextualism and Skepticism, „Philosophical Perspectives” 1999, Vol. 13, s. 91-114.

Kaplan D., Demonstratives, w: Themes from Kaplan, eds. J. Almog, J. Perry, H. Wettstein, Oxford University Press, Oxford 1989, s. 481-563.

Kölbel M., Faultless Disagreement, „Proceedings of the Aristotelian Society” 2004, Vol. 104, s. 53-73.

Lewis D., Elusive Knowledge, w: Skepticism. A Contemporary Reader, eds. K. DeRose, T.A. Warfield, Oxford University Press, Oxford 1999, s. 220-239.

Palczewski R., O wrażliwości kontekstowej zdań typu „S wie, że p”, „Analiza i Egzystencja" 2005, nr 2, s. 127-155.

Palczewski R., „Śledzący” kontekstualizm semantyczny, jego źródła i konsekwencje, „Filozofia Nauki” 2004, nr 12(1), s. 51-82.

Palczewski R., Wiedza w kontekstach. W obronie kontesktualizmu epistemicznego, t. I i II, Wydawnictwo Naukowe UMK, Toruń 2014.

Richard M., Contextualism and Relativism, „Philosophical Studies: An International Journal for Philosophy in the Analytic Tradition” 2004, Vol. 119, No. $1 / 2$, s. 215-242.

Schiffer S., Contextualist Solutions to Scepticism, „Proceedings of the Aristotelian Society, New Series" 1996, Vol. 96, s. 317-333.

Sosa E., Skepticism and Contextualism, „Philosophical Issues” 2000, Vol. 10, s. 1-18. Szubart T., O typach kawy. Kontekstualizm DeRose'a jako strategia antysceptycka, „Analiza i Egzystencja” 2018, nr 44, s. 61-81.

Yourgrau P., Knowledge and Relevant Alternatives, „Synthese” 1983, Vol. 55, No. 2, s. 175-190.

Weatherson B., Questioning Contextualism, w: Aspects of Knowing, ed. S. Hetherington, Elsevier Science, Amsterdam 2006, s. 133-147. 
Zwicky A., Sadock J., Ambiguity Tests and How to Fail Them, w: Syntax and Semantics, ed. J. Kimball, Vol. 4, New York Academic Press, New York 1975, s. 1-36.

\section{Streszczenie}

Celem artykułu jest zrekonstruowanie i krytyczna analiza trzech antykontekstualistycznych argumentów o różnym charakterze, wymierzonych w kontekstową zależność operatora wiedzy. Argumenty te można podzielić na dwie odrębne kategorie. Pierwsza zawiera takie argumenty, które znajdują łatwe i naturalne rozszerzenia w kontekście badania innych rodzajów wyrażeń uważanych zazwyczaj za wrażliwe kontekstowo. Druga jest specyficzna dla słowa „wiedzieć”. Rekonstrukcja trzech argumentów należących do tych kategorii (dwóch do pierwszej, jednego do drugiej) stanowi punkt wyjścia podjęcia oceny wybranych odpowiedzi udzielonych z punktu widzenia stanowiska kontekstualistycznego.

Słowa kluczowe: kontekstualizm, zdania przypisujące wiedzę, pozycja epistemiczna, standardy epistemiczne, parametry kontekstu, wyrażenia okazjonalne

\section{Summary}

\section{Three Arguments against Epistemic Contextualism}

Three anti-contextualist arguments of various character aimed at contextual dependence of the knowledge operator are reconstructed and critically analyzed in the paper. These arguments may be divided into two distinct categories. One category encompasses such arguments which are easily and naturally extendable against other sorts of expressions regarded as contextually sensitive. The second category is specific to the word "know”. Reconstruction of the three arguments belonging to these categories (two to the first one, one to the second one) is followed by the attempt to assess some contextualist responses which may be given to these arguments.

Key words: contextualism, sentences ascribing knowledge, epistemic position, epistemic standards, context parameters, occasional expressions 